\title{
A teratologic case in Oenopiella punctaria (Stål, 1859) (Heteroptera: Pentatomidae: Pentatominae: Carpocorini) from the Aisén region (Chile)
}

Un caso teratológico en Oenopiella punctaria (Stål, 1859) (Heteroptera: Pentatomidae: Pentatominae: Carpocorini) de la región de Aisén (Chile)

Eduardo I. Faúndez ${ }^{1,2}$ \& Alfredo Lüer ${ }^{3}$

\begin{abstract}
A teratological case is described in one specimen of Oenopiella punctaria (Stål, 1859) from Aisén Region, Chile. Malformations belongs to the group of the hemiteries (a pronotal dysplasia), and ectromelies (a right antennal atrophy). Possible causes of the teratological case are discussed.
\end{abstract}

Key words:

Heteroptera, Pentatomidae, Pentatominae, Carpocorini, teratology, Chile.

\section{Resumen}

Se describe un caso teratológico en un ejemplar de Oenopiella punctaria (Stål, 1859) de la Región de Aisén, Chile. Las malformaciones corresponden al grupo de las hemiterias (una displasia pronotal) y ectromelias (una atrofia antenal derecha). Se discuten las posibles causas de la teratosis.

Palabras clave:

Heteroptera, Pentatomidae, Pentatominae, Carpocorini, teratología, Chile.

\section{INTRODUCTION}

The teratosis are singular facts which occur on individuals, influencing on its ontogeny. However these facts can last on the time, and display on the phylogeny of a determined linage (Ortuño \& Ramos, 2008).

At world level, the major works about teratology on Hemipterans were undertaken by Balazuc (1951) and Štusak \& Sthelik (1977, 1978,
1979, 1980, 1982).

In Chile this discipline was highly fructiferous in the first half of the $20^{\text {th }}$ century (Pérez D'Angello, 1967). However, according Perez D'Angello (1967), the majority of the published reports from Chile belong to Coleoptera. Faúndez (2007) wrote that this tendency continue at the present years. In the country, for Heteroptera, there is just one case reported, in one species of Acanthosomatidae (Faúndez \& Carvajal, 2011).

Recent collections in the Aisén Region of Chile, allowed us to recognize a teratological case in Oenopiella punctaria (Stål, 1859) including hemiteries and ectromelies. Oenopiella punctaria is one of the 27 species of Pentatominae (Carpocorini) recorded from Chile (Faúndez \& Rider, 2014a), and it is also distributed in Argentina, Brazil and Uruguay (Fernández-Aldea et al. 2014). No further data is known about O. punctaria (e.g. bionomics, immature stages); like several other Chilean species of Carpocorini (Faúndez \& Rider, 2014b).

Among the teratosis, the ectromelies are defined as the lack or diminution of an appendix (Dallas, 1926). On the other hand the hemiteries are defined as general deformations and/or

1 Entomology Department, North Dakota State University, Dept. 7650, P.O. Box 6050; Fargo, ND ed.faundez@ gmail.com $\gg$

2 Departamento de Zoología Médica, Centro de Estudios en Biodiversidad (CEBCh), Magallanes, 1979, Osorno, Chile.

3 Panguilemo 261, Quilicura, Santiago, Chile, alfredoluer@ hotmail.com 
malformations (Dallas, 1926).

\section{MATERIALS AND METHODS}

For terminology and classification we follow Dallas (1926), Balazuc (1951) and Štusak \& Sthelik (1978). The specimen was prepared for dissection on barber's fluid for 12 hours. Photos were taken with a digital camera adapted to a stereoscopic microscope.

Material examined: Chile, Aisén Region, Coihaique, Balmaceda, 4542'25'S-7141'33'W, 10-II-2013, Leg. A. Lüer, 525 m s.n.m., 1 우 (Dissected, in alcohol on E. Faúndez coll.), under shrubs of typic patagonic stepe of Aisén (sensu Gajado, 1994).

\section{RESULTS}

Pronotal dysplasia (Figs. 1, 3, 5, 7)

Description: The pronotum has an enlarged median bump (Figs. 1, 3), which is absent in normal specimens. In lateral view it looks very convex compared to a normal specimen (Figs. 2, 4). This malformation produce stretching and contracting

Table I. measures (in millimeters) of the antennae of the teratolgical specimen of O. punctaria

\begin{tabular}{cccccc}
\hline Antennomere & I & II & III & IV & V \\
Right antenna & 0.42 & 0.51 & 0.57 & 0.71 & absent \\
Left antenna & 0.42 & 0.51 & 0.68 & 0.59 & 0.95 \\
\hline
\end{tabular}

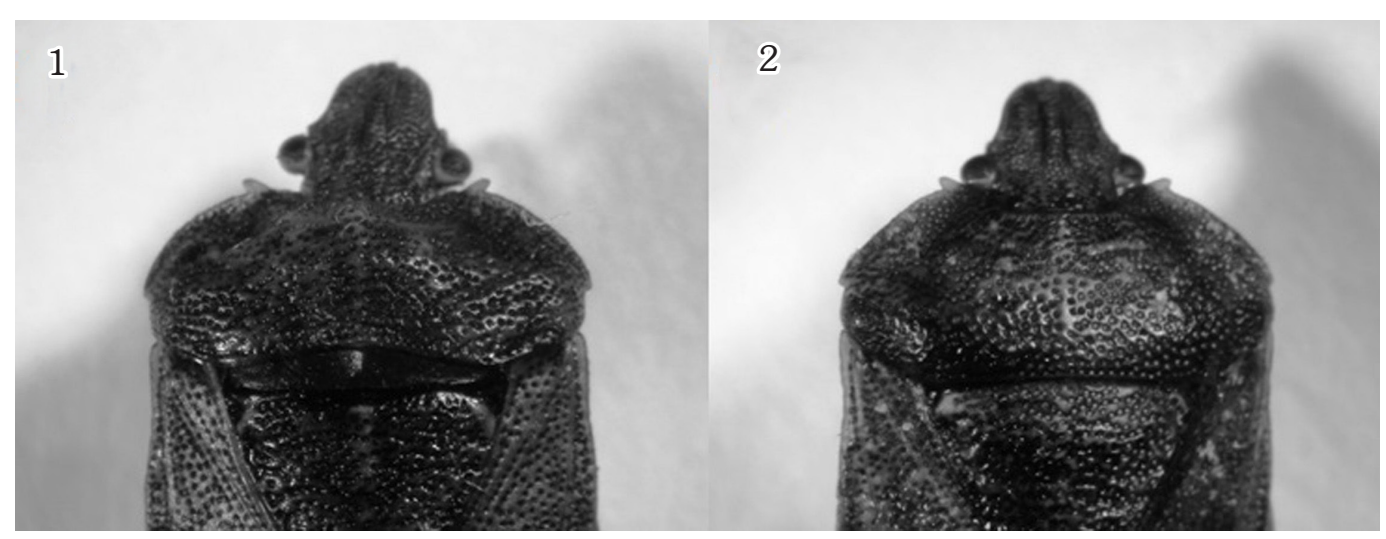

Figs. 1-2. Oenopiela punctaria. 1. Teratological specimen, pronotum, dorsal view; 2. Normal specimen, pronotum, dorsal view.

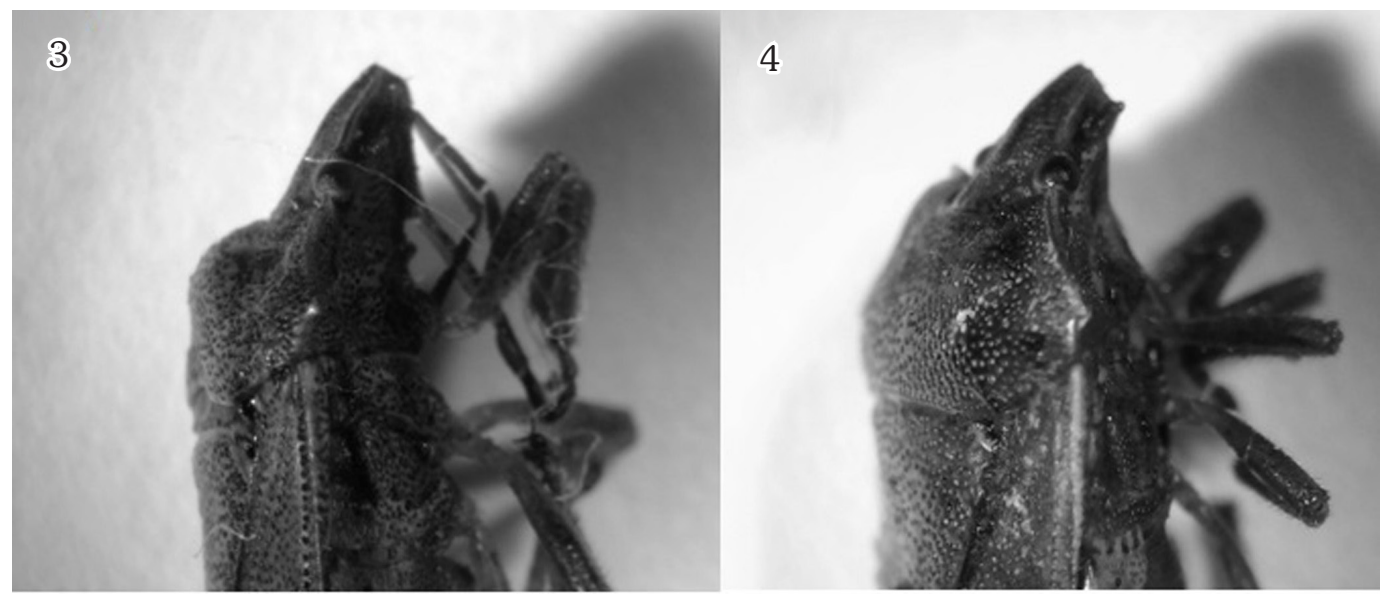

Figs. 3-4. Oenopiella punctaria. 3. Teratological specimen, lateral view; 4. Normal specimen, lateral view. 
of the tegument; leaving uncovered the anterior portion of the pterothorax (Fig. 7). Internally we found a rounded fatty tumor. After it removal, we found that the transverse muscles are attached more distally (Fig. 5) than in a normal specimen (Fig. 6)

Right antennal atrophy (Fig. 8)

Description: The right antenna has a multi-segment atrophy; the left antenna is normal (Fig. 8). The $5^{\text {th }}$ antennomere is absent. The $4^{\text {th }}$ antennomere is larger than the $4^{\text {th }}$ antennomere in the left antenna. The $3^{\text {rd }}$ antennomere is shorter than the $3^{\text {rd }}$ antennomere in the left antenna. $1^{\text {st }}$ and $2^{\text {nd }}$ antennomeres are normal.

\section{DISCUSSION AND CONCLUSIONS}

The dysplasias are a type of malformation relatively common in insects; however these are hard to study, because of its different possible origins (Balazuc, 1951). The antennal malformations are the most common in the Heteropterans (Costas

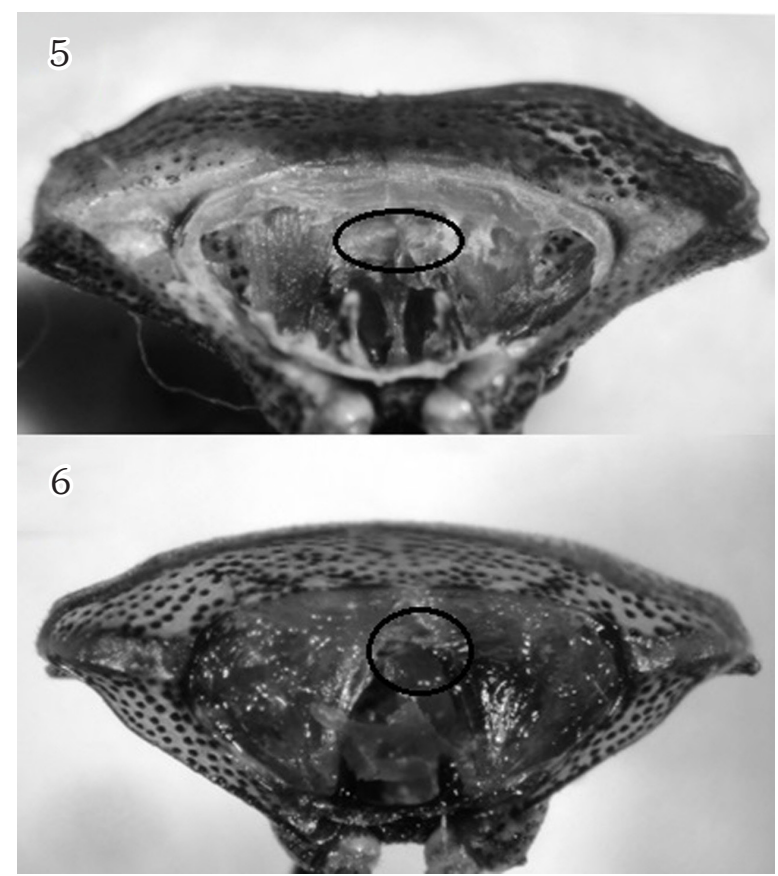

Figs 5-6. Oenopiella punctaria. 5. Teratological specimen, pronotum, internal view, muscles attachment circled; 6. Normal specimen, pronotum, internal view, muscles attachment circled.

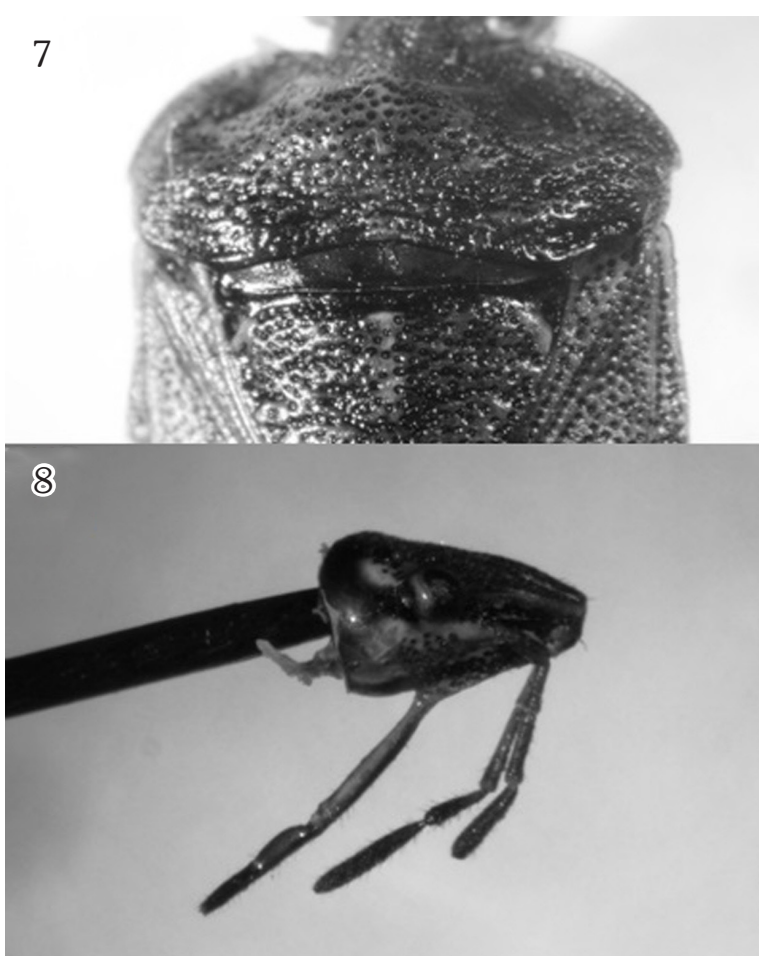

Figs. 7-8. Oenopiella punctaria. Teratological specimen. 7. Uncovered area of pterothorax; 8. Antennae, view from right side.

et al. 1992). Many of these malformations are originated because of injuries produced on immature stages, and posterior regenerations (Štusak \& Sthelik, 1978).

We believe possible that the malformations here described have in part exogenous origin (i.e. missing an antennomere during moulting and/or because a trauma); which subsequently, during the ontogeny, produced another endogenous teratosis (i.e. dysplasia, change in the relative length of antennomeres).

This case is also interesting because of the low number of teratosis reported for Heteropterans including two types of malformations.

\section{LITERATURE CITED}

Dallas, E. D. (1926). Anomalías en coleópteros chilenos. Revista Chilena de Historia Natural, 30, 73-83.

Balazuc, J. (1951). La tératologie des Hémiptères et groupes voisins. Annales de la Société entomologique de France, 120, 17-66. 
Costas, M. López, T. \& Vázquez, M. A. (1992). Teratologías en Lygaeidae (Heteroptera). Actas do $V$ Congreso Ibérico de Entomología, Lisboa, I, 313-322.

Fernández-Aldea, A. F., Barão, K. R., Grazia, J., \& Ferrari, A. (2014). An integrative approach to the taxonomy of Oenopiella Bergroth (Hemiptera: Heteroptera: Pentatomidae: Pentatominae: Carpocorini) with the description of two new species from Argentina and southern Brazil. Annals of the Entomological Society of America, 107(2), 364-381.

Faúndez E. I. (2007). Descripción de un caso teratológico en Aegorhinus vitulus (Fabricius, 1775) (Coleoptera: Curculionidae) de la región de Magallanes (Chile). Boletín de la Sociedad Entomológica Aragonesa, 40, 470.

Faúndez, E. I. \& Carvajal, M. A. (2011). Un caso teratológico en un ejemplar de Ditomotarsus punctiventris Spinola, 1852 (Hemiptera: Heteroptera: Acanthosomatidae) de Magallanes (Chile). Boletín de la Sociedad Entomológica Aragonesa, 48, 431-432.

Faúndez, E. I. \& Rider, D. A. (2014a). Nuevos registros de Pentatominae Leach, 1815 (Hemiptera: Heteroptera: Pentatomidae) en Chile. Boletín de la Sociedad Entomológica Aragonesa, 55, 159-162.

Faúndez, E. I. \& Rider, D. A. (2014b). Thestral incognitus, a new genus and new species of Pentatomidae from Chile (Heteroptera: Pentatomidae: Pentatominae: Carpocorini). Zootaxa, 3884(4), 394-400.

Gajardo, R. (1994). La vegetación natural de Chile.
Clasificación y distribuciones geográficas. Editorial Universitaria, Santiago, Chile.

Ortuño, V. M. \& Ramos Abuin, J. A. (2008). Reflexiones sobrelateratologíaydescripciones de cuatro teratosis apendiculares en Coleoptera. Boletín Sociedad Entomológica Aragonesa, 43, 435-439.

Pérez D’Angello, V. (1967). Contribución a la entomoteratología. Noticiario Mensual del Museo Natural de Historia Natural, 11(129), 4.

Štusak J. M. \& Sthelik, J. L. (1977). First contribution to the teratology of Tingidae (Heteroptera) reflexion and variability of paranota. Acta Musei Moraviae, Scientiae biologicae, 62, 119-122.

Štusak J. M. \& Sthelik, J. L. (1978). Second contribution to the teratology of Tingidae (Heteroptera) Antennal anomalies. Acta Musei Moraviae, Scientiae biologicae, 63, 89-105.

Štusak J. M. \& Sthelik, J. L. (1979). Third contribution to the teratology of Tingidae (Heteroptera) Anomalies of legs. Acta Musei Moraviae, Scientiae biologicae, 64, 75-84

Štusak J. M. \& Sthelik,J. L. (1980). Fourth contribution to the teratology of Tingidae (Heteroptera). Anomalies of head and thorax. Acta Musei Moraviae, Scientiae biologicae, 65, 161-172.

Štusak J. M. \& Sthelik, J. L. (1982). Fifth contribution to the teratology of Tingidae (Heteroptera). Anomalies of fore wings (Hemelytra). Acta Musei Moraviae, Scientiae biologicae, 67, 163-180. 